\title{
Proton Beam Therapy for Hepatocellular Carcinoma Patients with Severe Cirrhosis
}

\author{
Masaharu Hata1,2, Koichi Tokuuye 1,2, Shinji Sugahara2, Nobuyoshi Fukumitsu, 2, Takayuki Hashimoto, , \\ Kayoko Ohnishi², Keiko Nemoto², Kiyoshi Ohara², Yasushi Matsuzaki³ ${ }^{3}$, Yasuyuki Akine ${ }^{1,2}$
}

\begin{abstract}
Background and Purpose: Hepatocellular carcinoma (HCC) patients with severe cirrhosis are usually treated with supportive care because of their poor prognosis. However, the survival of severe cirrhotic patients has recently improved due to advanced treatments. The aim of this study was to define the role of proton beam therapy for HCC patients with severe cirrhosis.

Patients and Methods: 19 HCC patients with Child-Pugh class C cirrhosis received proton beam therapy. The hepatic tumors were solitary in 14 patients and multiple in five, and the tumor size was 25-80 mm (median $40 \mathrm{~mm}$ ) in maximum diameter. No patient had regional lymph node or distant metastasis. Total doses of 50-84 Gy (median 72 Gy) in ten to 24 fractions (median 16) were delivered to the tumors.

Results: Of the 19 patients, six, eight and four died of cancer, liver failure and intercurrent diseases, respectively, during the follow-up period of 3-63 months (median 17 months) after treatment. A remaining patient was alive with no evidence of disease 33 months after treatment. All but one of irradiated tumors were controlled during the follow-up period. Ten patients had new intrahepatic tumors outside the irradiated volume. The overall and progression-free survival rates were $53 \%$ and $47 \%$ at 1 year, respectively, and $42 \%$ each at 2 years. Performance status and Child-Pugh score were significant prognostic factors for survival. Therapy-related toxicity of grade 3 or more was not observed.

Conclusion: Proton beam therapy for HCC patients with severe cirrhosis was tolerable. It may improve survival for patients with relatively good general condition and liver function.
\end{abstract}

Key Words: Hepatocellular carcinoma · Proton beam therapy · Radiation therapy · Severe cirrhosis

Strahlenther Onkol 2006;182:713-20

DOI 10.1007/s00066-006-1564-2

\section{Protonentherapie bei Patienten mit Leberzellkarzinom und schwerer Zirrhose}

Hintergrund und Ziel: Patienten mit Leberzellkarzinom (HCC [„hepatocellular carcinoma“]) und schwerer Zirrhose werden aufgrund der schlechten Prognose gewöhnlich konservativ behandelt. Allerdings haben fortschrittliche Therapien in letzter Zeit zu einer Verbesserung der Überlebenszeit von Patienten mit schwerer Zirrhose geführt. Das Ziel der vorliegenden Studie war die Bestimmung der Rolle einer Protonentherapie für HCC-Patienten mit schwerer Zirrhose.

Patienten und Methodik: 19 HCC-Patienten mit Zirrhose der Child-Pugh-Klasse C wurden mit Protonenstrahlen behandelt. 14 Patienten wiesen einzelne und fünf Patienten multiple Lebertumoren auf. Hinsichtlich der Tumorgröße variierte der maximale Durchmesser dabei zwischen 25 und $80 \mathrm{~mm}$ (durchschnittlich $40 \mathrm{~mm}$ ). Keiner der Patienten hatte regionäre Lymphknoten- oder Fernmetastasen in regionären oder entfernten Lymphknoten. Die Gesamtstrahlendosis betrug 50-84 Gy (durchschnittlich 72 Gy) und wurde in zehn bis 24 Fraktionen (durchschnittlich 16 Fraktionen) verabreicht.

Ergebnisse: Im Nachuntersuchungszeitraum von 3-63 Monaten (durchschnittlich 17 Monate) verstarben sechs der insgesamt 19 Patienten an Krebs, acht an Leberversagen und vier an interkurrierenden Erkrankungen. Ein Patient war 33 Monate nach der Behandlung ohne Krankheitszeichen am Leben. Mit einer Ausnahme wurden alle Tumoren während der Nachuntersuchung mit entsprechenden Kontrollen verglichen. Zehn Patienten hatten intrahepatische Tumoren, die außerhalb des bestrahlten Bereichs lagen. Die Gesamt- und die progressionsfreie Überlebensrate betrugen nach 1 Jahr 53\% und 47\% und nach 2 Jahren $42 \%$. Der Performance-Status und die Child-Pugh-Bewertung waren wichtige prognostische Faktoren für das Überleben.

Schlussfolgerung: Die Protonentherapie war für Patienten mit Leberzellkarzinom und schwerer Zirrhose tolerabel. Die Behandlung könnte das Überleben von Patienten mit relativ gutem Allgemeinzustand und guter Leberfunktion verbessern.

Schlüsselwörter: Leberzellkarzinom · Protonentherapie · Strahlentherapie · Schwere Zirrhose

\footnotetext{
${ }^{1}$ Proton Medical Research Center, University of Tsukuba, Tsukuba, Ibaraki, Japan,

${ }^{2}$ Department of Radiation Oncology, University of Tsukuba, Tsukuba, Ibaraki, Japan,

${ }^{3}$ Department of Gastroenterology and Hepatology, University of Tsukuba, Tsukuba, Ibaraki, Japan.
}

Received: January 27, 2006; accepted: July 12, 2006 


\section{Introduction}

Currently, hepatocellular carcinoma (HCC) patients can be effectively treated with various modalities, i.e., surgical resection, transcatheter arterial embolization (TAE) and infusion chemotherapy (TAI), percutaneous ethanol injection (PEI) and microwave coagulation (PMC), and radiofrequency ablation (RFA) [16]. However, these treatment modalities are often unsuitable for patients with severe cirrhosis because of the potential risk of liver failure or bleeding; furthermore, their prognosis is poor due to severe cirrhosis [8]. Therefore, HCC patients with severe cirrhosis are usually treated with palliative or supportive care [3].

At our institute, University of Tsukuba, Japan, proton beams have been employed in treatment for a variety of malignancies including HCC since 1983 [4, 11, 19, 30]. Proton beam irradiation yields theoretically excellent dose localization to the target due to sharp distal fall-off of the Bragg peak compared with photon irradiation, and consequently can reduce the irradiated volume and dose given to the hepatic parenchyma and digestive tract for HCC patients, while increasing the dose to the tumor $[12,21,26,28]$.

Table 1. Patient and tumor characteristics. HBV: hepatitis B virus; HCV: hepatitis C virus; AFP: $\alpha$-fetoprotein.

Tabelle 1. Patienten- und Tumorcharakteristika. HBV: Hepatitis-BVirus; HCV: Hepatitis-C-Virus; AFP: $\alpha$-Fetoprotein.

\begin{tabular}{|c|c|}
\hline Total number of patients & 19 \\
\hline $\begin{array}{l}\text { Gender } \\
\text { - Male } \\
\text { - Female }\end{array}$ & $\begin{array}{c}14 \\
5\end{array}$ \\
\hline $\begin{array}{l}\text { Age (years) } \\
\text { - Range } \\
\text { - Median }\end{array}$ & $\begin{array}{l}51-69 \\
61\end{array}$ \\
\hline $\begin{array}{l}\text { Performance status } \\
\text { - } 0 \\
\text { - } 1 \\
\text { - } 2\end{array}$ & $\begin{array}{c}1 \\
10 \\
8\end{array}$ \\
\hline $\begin{array}{l}\text { Etiology of cirrhosis } \\
\text { - HBV } \\
\text { - HCV } \\
\text { - Alcohol }\end{array}$ & $\begin{array}{c}1 \\
16 \\
2\end{array}$ \\
\hline $\begin{array}{l}\text { Child-Pugh score } \\
\text { - } 10 \\
\text { - } 11 \\
\text { - } 12 \\
\text { - } 13 \\
\text { - } 14\end{array}$ & $\begin{array}{l}4 \\
2 \\
8 \\
3 \\
2\end{array}$ \\
\hline $\begin{array}{l}\text { Number of tumors } \\
\text { - Solitary } \\
\text { - Multiple }\end{array}$ & $\begin{array}{c}14 \\
5\end{array}$ \\
\hline $\begin{array}{l}\text { Tumor size (mm) } \\
\text { - Range } \\
\text { - Median }\end{array}$ & $\begin{array}{l}25-80 \\
40\end{array}$ \\
\hline $\begin{array}{l}\text { Serum AFP value }(\mathrm{ng} / \mathrm{ml}) \\
\text { - Range } \\
\text { - Median }\end{array}$ & $\begin{array}{l}2-12,53 \\
93\end{array}$ \\
\hline
\end{tabular}

We present herein the treatment results of proton beam therapy for HCC patients with severe cirrhosis.

\section{Patients and Methods \\ Patients}

Between November 1990 and January 2000, 197 HCC patients received proton beam therapy. Of these patients, 19 had severe cirrhosis categorized as Child-Pugh class $\mathrm{C}$ at the initiation of proton beam therapy [25]. All patients were inoperable, and TAE and TAI were contraindicated due to the potential risk of liver failure. PEI, PMC and RFA were unfeasible because of bleeding tendency, large-sized tumors, or unfavorable tumor location. There were no other available treatment modalities for these patients. Exclusion criteria for proton beam therapy included extrahepatic metastasis, diffusely infiltrated tumor, and poor general condition of the Eastern Cooperative Oncology Group (ECOG) performance status $\geq 3[23]$.

HCCs were diagnosed histopathologically by biopsy in eight patients, and clinically by medical imaging; contrast-enhanced computed tomography $(\mathrm{CT})$ or magnetic resonance imaging (MRI), and elevated serum $\alpha$-fetoprotein (AFP) values in eleven patients. None had regional lymph node enlargement or distant metastasis. 14 and five patients were diagnosed clinically as stage I (T1 N0 M0) and stage II (T2 N0 M0), respectively, based on the TNM classification defined by the International Union Against Cancer (UICC), at the time of proton beam irradiation [27].

Patient and tumor characteristics are summarized in Table 1. Written informed consent was obtained from all patients before initiation of proton beam therapy.

\section{Proton Beam Therapy}

Metallic fiducial markers for proton beam therapy were implanted percutaneously into the hepatic parenchyma beside the tumors. Treatment planning for proton beam therapy was based on CT images at 5-mm intervals in the treatment position. Clinical target volume (CTV) was defined as gross tumor volume plus 5-mm margin. Planning target volume, which included CTV with 5-mm margin, was homogeneously set at the $100 \%$ dose level by utilizing the spread-out Bragg peak (SOBP) of proton beams (Figure 1). Multiple hepatic tumors, which were observed in five patients, were entirely included within the target volume.

Proton beams generated by a booster synchrotron of the High Energy Accelerator Research Organization were degraded to $\leq 250 \mathrm{MeV}$ for clinical use. The beams synchronized with respiration were delivered through the horizontal or vertical port for treatment. Respiratory gating was controlled by means of a strain gauge (Kyowa Electronic Instruments, Tokyo, Japan) attached to the abdominal surface of the patients, so that proton beams were delivered to the tumors in expiratory phase when the tumor position was considered to be most stable and reproducible $[13,22]$. For each treatment 
Figure 1. Isodose distribution with the anterior and right lateral proton beams in a hepatocellular carcinoma patient with severe cirrhosis. Each isodose line corresponds to $90 \%, 50 \%, 30 \%$, and $10 \%$ dose levels from the inside out, respectively. The critical organs such as the spinal cord and the digestive tracts are located entirely outside the irradiated volume due to sharp distal fall-off of the Bragg peak of proton beams.

Abbildung 1. Isodosenverteilung bei anteriorem und lateralem Protonenstrahl bei einem Patienten mit Leberzellkarzinom und schwerer Zirrhose. Jede Isodosenlinie von innen nach außen entspricht jeweils $90 \%, 50 \%, 30 \%$ und 10\%. Die kritischen Organe wie das Rückenmark und der Verdauungstrakt liegen wegen des scharfen distalen Abfalls der Bragg-Spitze des Protonenstrahls vollständig außerhalb des bestrahlten Volumens.

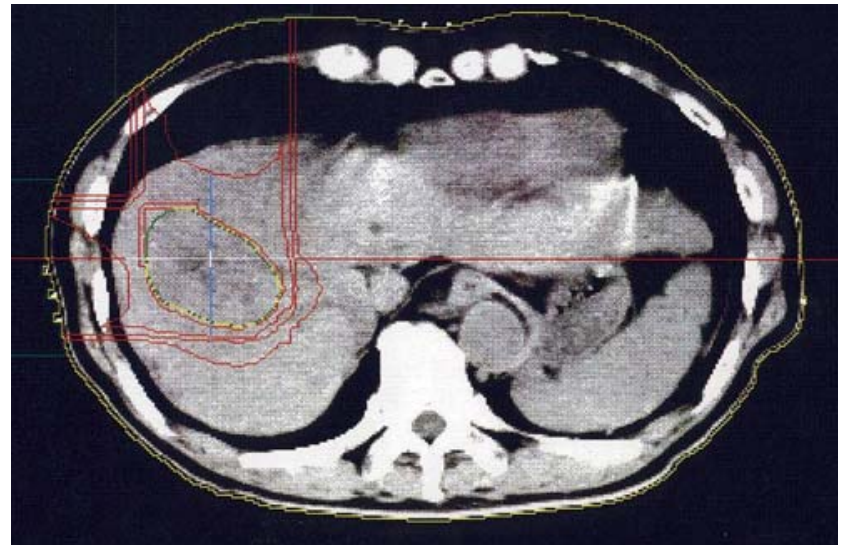

session, the positional relationship between the center of the target and the fiducial markers was examined, with the patients lying in the treatment position, by the fluoroscopy unit attached to the treatment unit.

Fraction size was 3-5 Gy daily, 3-5 days per week; total doses were 50-84 Gy (median 72 Gy) in ten to 24 fractions (median 16). A relative biological effectiveness value of 1.0 was utilized in accordance with data obtained from fibrosarcoma NFSa cells [2]. Evaluation by doses of 2 Gy per fractionequivalent calculated using a linear-quadratic model with $\alpha / \beta$ ratios of 10 and 3 for early and late responding tissues revealed total doses equivalent to 63-95 Gy (median $87 \mathrm{~Gy}$ ) and 79-109 Gy (median 107 Gy), respectively [31].

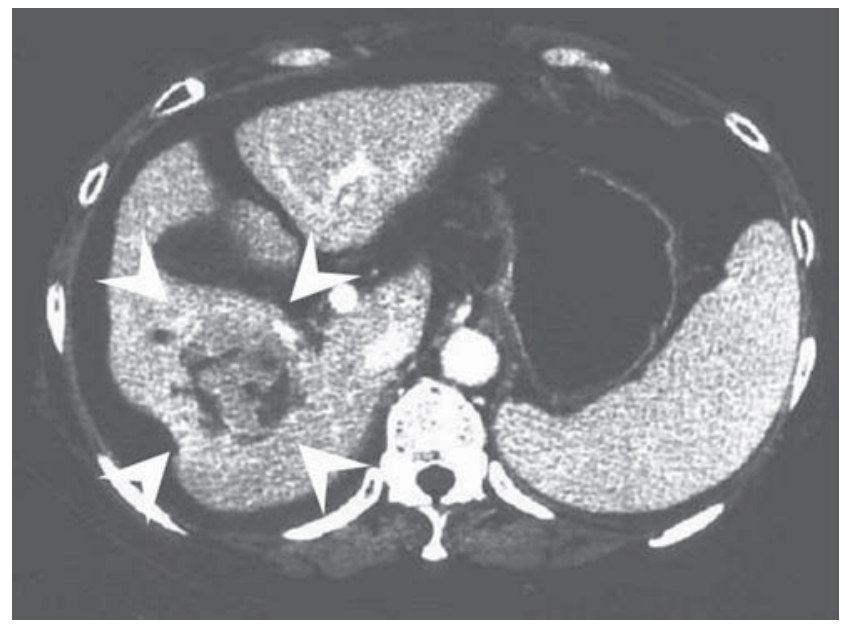

Figure 2a - Abbildung 2a

Follow-up Procedure and Evaluation Criteria

The patients had serum AFP value measurements and abdominal imaging studies (CT or MRI) approximately 1 and 2 months after completion of proton beam therapy, respectively, and then were followed at intervals of 1-3 months. Local responses to proton beam therapy were classified according to the World Health Organization (WHO) response evaluation criteria [20]. No growth of the irradiated tumors was defined as progression-free.

Acute and late toxicities associated with treatment were evaluated with RTOG acute radiation morbidity scoring criteria and RTOG/EORTC late radiation morbidity scoring scheme, respectively [5].

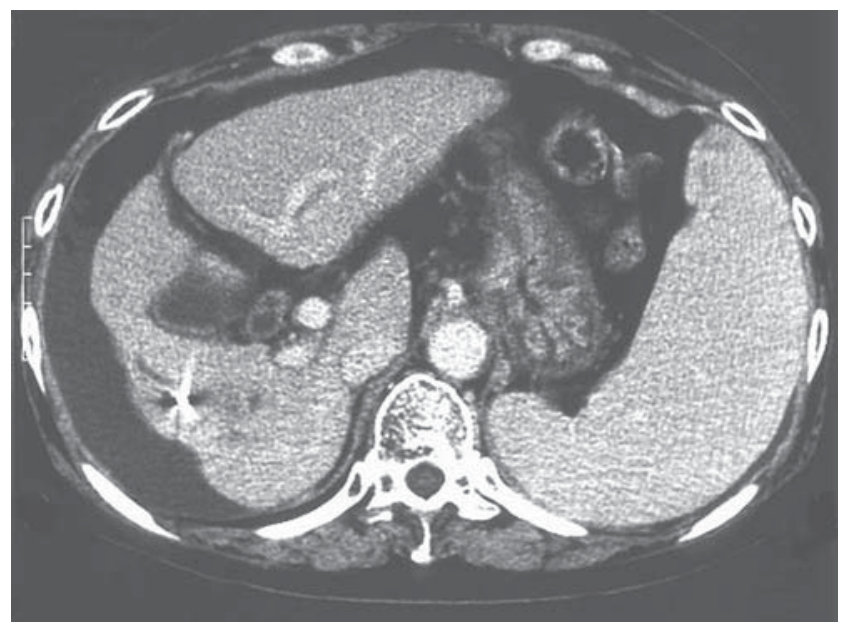

Figure $\mathbf{2 b}$ - Abbildung $\mathbf{2 b}$

Figures $\mathbf{2 a}$ and $\mathbf{2 b}$. Contrast-enhanced CT in arterial phase of a hepatocellular carcinoma patient with severe cirrhosis. a) Just before initiation of proton beam therapy. Arrowheads represent position of the hepatic tumor enhanced inhomogeneously. b) 7 months after completion of proton beam therapy. The marked reduction of the tumor volume is demonstrated. The intrahepatic high-density region corresponds to an implanted metallic fiducial marker.

Abbildungen 2a und 2b. Kontrastverstärkte CT-Aufnahme in der arteriellen Phase bei einem Patienten mit Leberzellkarzinom und schwerer Zirrhose. a) Unmittelbar vor Beginn der Protonentherapie. Die Pfeilspitzen geben die Lage des inhomogen verstärkten Leberzellkarzinoms an. b) 7 Monate nach Abschluss der Protonentherapie. Die deutliche Reduktion des Tumorvolumens ist auffällig. Der intrahepatische Bereich erhöhter Dichte repräsentiert ein implantiertes metallisches Achsenkreuz. 


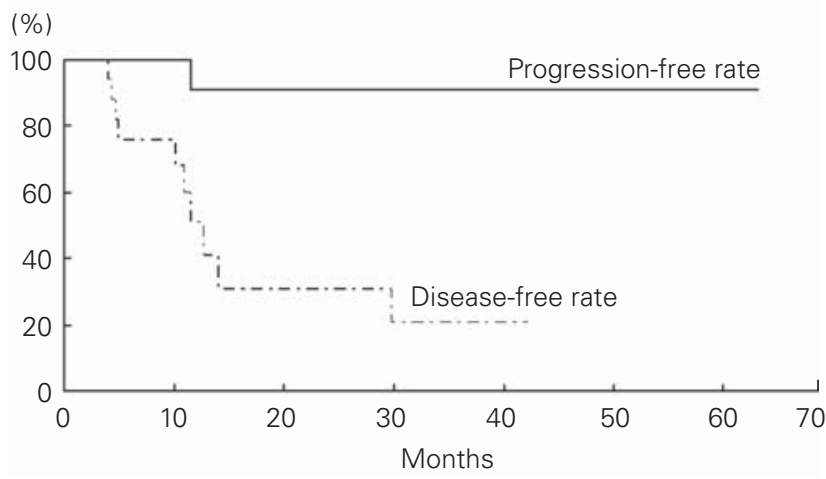

Figure 3. Progression-free and disease-free rates of 19 hepatocellular carcinoma patients with severe cirrhosis treated with proton beams.

Abbildung 3. Progressionsfreie und krankheitsfreie Raten der Patienten mit Leberzellkarzinom und schwerer Zirrhose, die eine Protonentherapie erhielten.

\section{Statistical Analysis}

The actuarial survival rates and the progression- and disease-free rates were calculated according to the Kaplan-Meier method [14]. The prognostic factors for survival were evaluated by the log-rank test [1]. The changes of variables in blood tests were examined by the paired t-test. $\mathrm{p}<0.05$ was considered statistically significant. All statistical analyses were performed using the statistical software SPSS 11.0J (SPSS Inc., Chicago, IL, USA).

\section{Results}

\section{Tumor Control and Failure Patterns}

Tumor responses were complete response (CR) in nine patients, partial response (PR) in three, no change (NC) in six, and progressive disease (PD) in one. The objective response (CR and $\mathrm{PR}$ ) rate was $63 \%$. The pre- and posttreatment CT images of a patient are shown in Figure 2. Consequently, all but one of irradiated tumors were controlled at the median follow-up period of 17 months (range, 3-63 months) after treatment; the progression-free rate was $91 \%$. AFP values of 14 patients which had shown high levels of 30-12,539 $\mathrm{ng} / \mathrm{ml}$ (median $145 \mathrm{ng} / \mathrm{ml}$ ) beyond the upper normal limit of $20 \mathrm{ng} / \mathrm{ml}$ before irradiation decreased to 1-2,141 $\mathrm{ng} / \mathrm{ml}$ (median $19 \mathrm{ng} / \mathrm{ml}$ ), to normal range in seven patients, after irradiation.

Ten patients had new hepatic tumors outside the irradiated volume 4-30 months after treatment. None had distant metastases. Of the ten patients with recurrence, two (patients \# 1 and 2) received second courses of proton beam therapy and all recurrent tumors were controlled after reirradiation. For the remaining eight patients, radical treatment was considered contraindicated due to further deteriorated cirrhosis.

The disease-free rates were $51 \%$ at 1 year and $31 \%$ at 2 years (Figure 3). The summaries of all patients divided into two groups according to survival time (over or within 1 year) are shown in Tables 2 and 3 .

\section{Pre- and Posttreatment Liver Function}

Pre- and posttreatment (1 month after treatment) mean \pm standard deviation (SD) values of serum albumin and total bilirubin, prothrombin activity, and platelets, and those during treatment in all patients are summarized in Table 4. Although the mean value of total bilirubin increased and that of platelets decreased transiently during treatment, in comparison with each pretreatment mean value, there were no sig-

Table 2. Summary of ten hepatocellular carcinoma patients with severe cirrhosis who survived for $>1$ year after proton beam therapy. CR: complete response; F: female; HBV: hepatitis B virus; $\mathrm{HCV}$ : hepatitis C virus; ICH: intracranial hemorrhage; IOIV: inside and outside of the irradiated volume; M: male; NED: no evidence of disease; OIV: outside of the irradiated volume; PD: progressive disease; PR: partial response; PS: performance status.

Tabelle 2. Zusammenfassung der zehn Patienten mit Leberzellkarzinom und schwerer Zirrhose, die > 1 Jahr nach der Protonentherapie überlebten. CR: Komplettremission; F: weiblich; HBV: Hepatitis-B-Virus; HCV: Hepatitis-C-Virus; ICH: intrakranielle Blutung; IOIV: innerhalb und außerhalb des bestrahlten Bereichs; M: männlich; NED: keine Krankheitszeichen; OIV: außerhalb des bestrahlten Bereichs; PD: fortschreitende Erkrankung; PR:Teilremission; PS: Performance-Status.

\begin{tabular}{|c|c|c|c|c|c|c|c|c|c|c|}
\hline $\begin{array}{l}\text { Patient } \\
\#\end{array}$ & $\begin{array}{l}\text { Age (years)/ } \\
\text { gender }\end{array}$ & PS & $\begin{array}{l}\text { Etiology } \\
\text { of cirrhosis }\end{array}$ & $\begin{array}{l}\text { Child- } \\
\text { Pugh } \\
\text { score }\end{array}$ & $\begin{array}{l}\text { Number of } \\
\text { tumors }\end{array}$ & $\begin{array}{l}\text { Tumor } \\
\text { size } \\
(\mathrm{mm})\end{array}$ & $\begin{array}{l}\text { Total dose } \\
\text { (Gy/fractions) }\end{array}$ & $\begin{array}{l}\text { Tumor } \\
\text { response }\end{array}$ & $\begin{array}{l}\text { Pattern of } \\
\text { failure }\end{array}$ & $\begin{array}{l}\text { Follow-up } \\
\text { (months) } \\
\text { and status }\end{array}$ \\
\hline 1 & $67 / M$ & 1 & $\mathrm{HCV}$ & 10 & Solitary & 50 & $84 / 24$ & CR & Liver (OIV) & 63, dead of trauma \\
\hline 2 & $54 / M$ & 1 & $\mathrm{HCV}$ & 10 & Multiple & 25 & $84 / 24$ & $\mathrm{CR}$ & Liver (OIV) & 56, dead of cancer \\
\hline 3 & $68 / M$ & 2 & $\mathrm{HCV}$ & 13 & Solitary & 35 & $72.5 / 19$ & CR & None & 42 , dead of liver failure \\
\hline 4 & $66 / F$ & 0 & Alcohol & 12 & Solitary & 30 & $72 / 16$ & $\mathrm{CR}$ & Liver (OIV) & 37, dead of cancer \\
\hline 5 & $63 / F$ & 2 & $\mathrm{HCV}$ & 12 & Solitary & 60 & $67.5 / 15$ & PR & Liver (OIV) & 17, dead of cancer \\
\hline 6 & $60 / F$ & 1 & $\mathrm{HCV}$ & 11 & Solitary & 40 & $72 / 16$ & $\mathrm{CR}$ & Liver (OIV) & 57, dead of ICH \\
\hline 7 & $52 / M$ & 2 & $\mathrm{HCV}$ & 14 & Solitary & 35 & $50 / 10$ & PD & Liver (IOIV) & 19, dead of liver failure \\
\hline 8 & $59 / M$ & 1 & $\mathrm{HCV}$ & 10 & Solitary & 35 & $72 / 16$ & $\mathrm{CR}$ & Liver (OIV) & 32, dead of cancer \\
\hline 9 & $66 / M$ & 1 & $\mathrm{HCV}$ & 11 & Solitary & 30 & $72 / 16$ & CR & Liver (OIV) & 45, dead of liver failure \\
\hline 10 & $53 / M$ & 1 & $\mathrm{HCV}$ & 12 & Solitary & 35 & $50 / 10$ & CR & None & 33, alive with NED \\
\hline
\end{tabular}


Table 3. Summary of nine hepatocellular carcinoma patients with severe cirrhosis who died within 1 year after proton beam therapy. CR: complete response; F: female; HBV: hepatitis B virus; HCV: hepatitis C virus; ICH: intracranial hemorrhage; IP: interstitial pneumonitis; M: male; NC: no change; OIV: outside of the irradiated volume; PR: partial response; PS: performance status.

Tabelle 3. Zusammenfassung der neun Patienten mit Leberzellkarzinom und schwerer Zirrhose, die innerhalb 1 Jahres nach der Protonentherapie verstarben. CR: Komplettremission; F: weiblich; HBV: Hepatitis-B-Virus; HCV: Hepatitis-C-Virus; ICH: intrakranielle Blutung; IP: interstitielle Pneumonitis; M: männlich; NC: stabile Erkrankung; OIV: außerhalb des bestrahlten Bereichs; PR: Teilremission; PS: Performance-Status.

\begin{tabular}{lllllllllll}
\hline $\begin{array}{l}\text { Patient } \\
\#\end{array}$ & $\begin{array}{l}\text { Age (years)/ } \\
\text { gender }\end{array}$ & PS & $\begin{array}{l}\text { Etiology } \\
\text { of cirrhosis }\end{array}$ & $\begin{array}{l}\text { Child- } \\
\text { Pugh } \\
\text { score }\end{array}$ & $\begin{array}{l}\text { Number of } \\
\text { tumors }\end{array}$ & $\begin{array}{l}\text { Tumor } \\
\text { size } \\
(\mathbf{m m})\end{array}$ & $\begin{array}{l}\text { Total dose } \\
\text { (Gy/fractions) }\end{array}$ & $\begin{array}{l}\text { Tumor } \\
\text { response }\end{array}$ & $\begin{array}{l}\text { Pattern of } \\
\text { failure }\end{array}$ & $\begin{array}{l}\text { Follow-up } \\
\text { (months) } \\
\text { and status }\end{array}$ \\
\hline 11 & $60 / M$ & 2 & HCV & 12 & Multiple & 45 & $77 / 22$ & CR & None & 4 , dead of ICH \\
12 & $62 / M$ & 1 & HBV & 13 & Solitary & 36 & $84 / 24$ & NC & None & 5 , dead of liver failure \\
13 & $57 / M$ & 2 & HCV & 10 & Solitary & 80 & $64 / 15$ & NC & None & 3 , dead of IP \\
14 & $62 / M$ & 1 & HCV & 12 & Multiple & 55 & $72 / 18$ & PR & None & 10, dead of liver failure \\
15 & $62 / M$ & 2 & HCV & 12 & Solitary & 30 & $68.8 / 16$ & PR & Liver (OIV) & 6 , dead of cancer \\
16 & $58 / F$ & 1 & Alcohol & 12 & Solitary & 40 & $68 / 14$ & NC & Liver (OIV) & 6 , dead of cancer \\
17 & $69 / M$ & 2 & HCV & 14 & Multiple & 41 & $72 / 16$ & NC & None & 5 , dead of liver failure \\
18 & $66 / M$ & 1 & HCV & 13 & Solitary & 57 & $72 / 16$ & NC & None & 12, dead of liver failure \\
19 & $61 / F$ & 2 & HCV & 12 & Multiple & 55 & $66 / 22$ & NC & None & 6 , dead of liver failure \\
\hline
\end{tabular}

nificant differences between the pre- and posttreatment mean values (Figure 4).

There was no deterioration in Child-Pugh score, but rather an improvement in 14 patients.

\section{Survival and Prognostic Factors}

Of 19 patients, six and eight died of cancer 6-56 months and liver failure 5-45 months after treatment, respectively. Of the remaining five patients, four died of intercurrent diseases ( $n=2$ intracranial hemorrhage, $n=1$ trauma, and $n=1$ interstitial pneumonitis due to coexisting pulmonary fibrosis) and another was alive with no evidence of disease 33 months after treatment. The progression-free survival rates were $47 \%$ at 1 year and $42 \%$ at 2 years, and the median progression-free survival time was 12 months (Figure 5). The overall survival rates were $53 \%$ and $42 \%$ at 1 and 2 years, respectively, and the median overall survival time was 17 months (Figure 6).

Performance status and Child-Pugh score were significant prognostic factors for survival (Table 5).

\section{Toxicity}

Acute reactions of grade 2 or less occurred in six patients (Table 6). These toxicities were transient and easily manageable and caused no interruption of the treatment.

No late toxicities associated with the treatment were observed.

\section{Discussion}

Although the clinical significance of treatment for $\mathrm{HCC}$ in patients with severe cirrhosis is still unknown, it is currently believed that radical treatment for HCC hardly ever contributes to prolonging survival of the patients. This hypothesis is based on the poor prognosis of severe cirrhosis itself. However, according to some reports the prognosis of severe cir- rhotic patients has recently improved due to advanced treatments for liver dysfunction or esophageal varices. Planas et al. reported that the 1-year survival rate in Child-Pugh class $\mathrm{C}$ cirrhotic patients was $75 \%$ and some patients survived for $>5$ years [24].

On the other hand, the median survival time of HCC patients with Child-Pugh class $\mathrm{C}$ cirrhosis treated only with supportive care was 3-9 months and all such patients died within 3 years $[3,17,18]$. These data suggest that the control of HCC may result in improvement of prognosis even for patients with severe cirrhosis. However, surgical resection is generally unfeasible because of the high risk of liver failure or bleeding [6,9]. Aggressive transcatheter arterial chemoembolization (TACE) resulted in the death of $25 \%$ of Child-Pugh class $\mathrm{C}$ cirrhotic patients due to fatal complications including gastroduodenal bleeding within 1 month after treatment [18]. PEI may be one of the most feasible modalities for small

Table 4. Mean values \pm SD in serum albumin, total bilirubin, prothrombin activity, and platelets before, during and at 1 month after proton beam therapy. SD: standard deviation.

Tabelle 4. Mittelwert \pm SD für Serumalbumin, Gesamtbilirubin, Prothrombinaktivität und Plättchen vor, während und 1 Monat nach der Protonentherapie. SD: Standardabweichung.

\begin{tabular}{lccc}
\hline Variable & $\begin{array}{l}\text { Before } \\
\text { treatment } \\
\text { Mean } \pm \text { SD }\end{array}$ & $\begin{array}{l}\text { During } \\
\text { treatment }^{\text {a }}\end{array}$ & $\begin{array}{l}\text { After } \\
\text { treatment }\end{array}$ \\
\hline Albumin $(\mathrm{g} / \mathrm{dl})$ & $2.7 \pm 0.3$ & $2.6 \pm 0.3$ & $3.0 \pm 0.6$ \\
Total bilirubin $(\mathrm{mg} / \mathrm{dl})$ & $2.8 \pm 1.1$ & $3.6 \pm 1.5$ & $3.3 \pm 1.5$ \\
Prothrombin activity $(\%)$ & $58.0 \pm 13.8$ & $55.1 \pm 9.4$ & $56.8 \pm 10.0$ \\
Platelets $\left(\times 10^{4} / \mu \mathrm{l}\right)$ & $6.9 \pm 3.2$ & $4.9 \pm 1.5$ & $6.2 \pm 2.2$ \\
\hline
\end{tabular}

${ }^{\text {a }}$ mean $\pm S D$ of minimum values in albumin, prothrombin activity and platelets and of maximum values in total bilirubin for individuals 
HCC with favorable tumor location. Nevertheless, the overall survival rates were $40-81 \%$ at 1 year and none survived for $>2$ years. Furthermore, severe and fatal complications such as hemoperitoneum, hepatic infarction and abscess, and tumor-
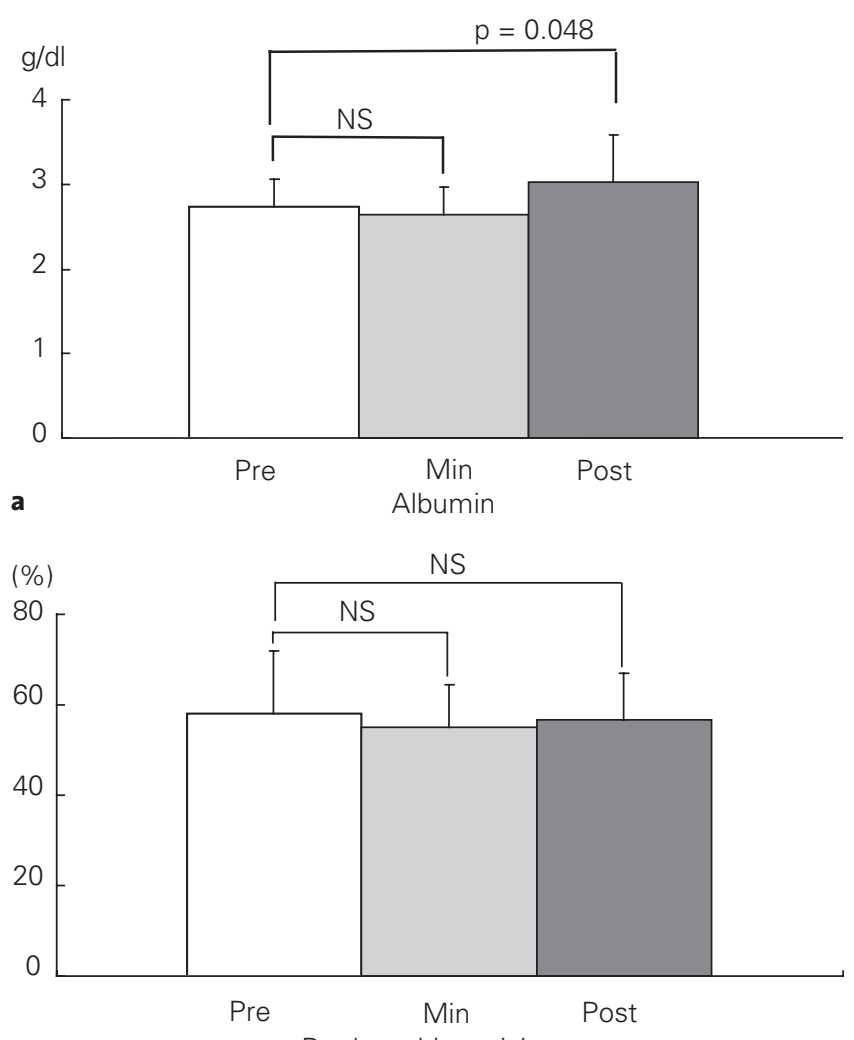

c Prothrombin activity

al seeding occurred in some cases, along with uncomfortable symptoms such as fever and pain in many cases [7, 10, 15]. Although RFA is also anticipated to be a less invasive modality, its efficacy has never been demonstrated in patients with
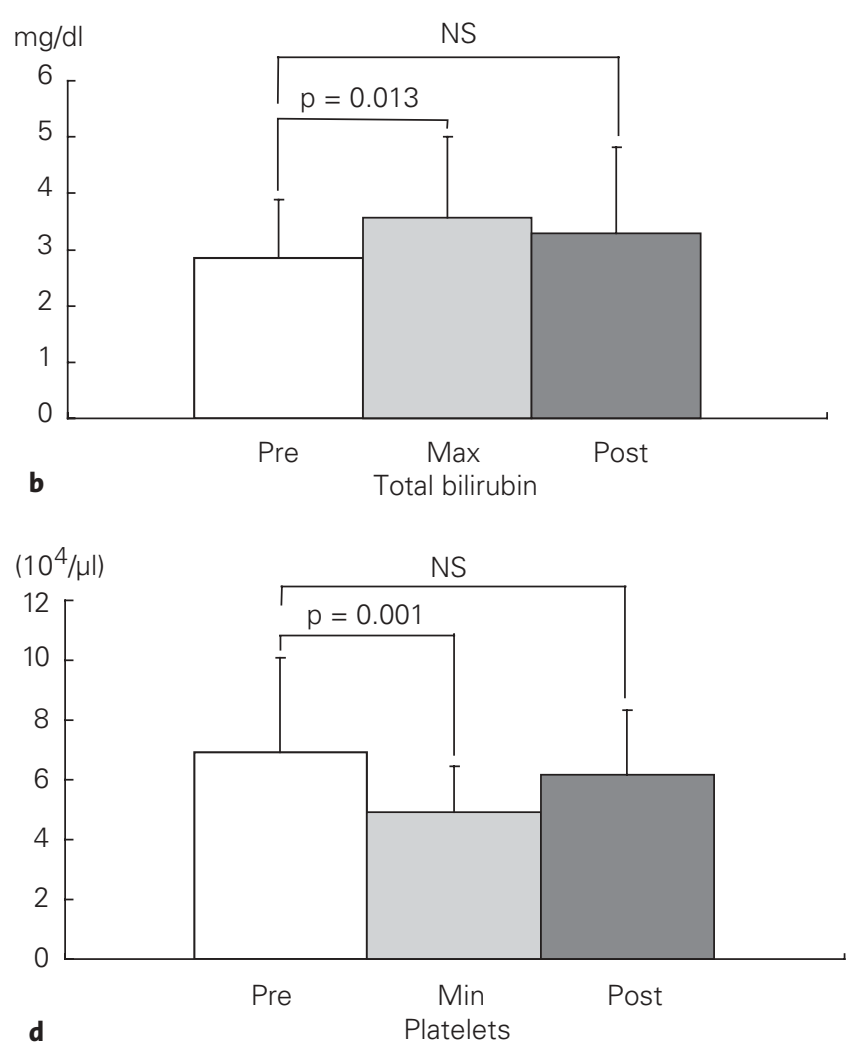

Figures $4 \mathrm{a}$ to $4 \mathrm{~d}$. Pretreatment (Pre), maximum (Max) or minimum (Min) during treatment, and posttreatment (Post) mean values \pm SD of a) serum albumin, b) total bilirubin, c) prothrombin activity, and d) platelets. NS: not significant.

Abbildungen 4a bis 4d. Prätherapeutische (Pre), maximale (Max) oder minimale (Min) Werte während der Behandlung sowie posttherapeutische (Post) Mittelwerte \pm SD für a) Serumalbumin, b) Gesamtbilirubin, c) Prothrombinaktivität und d) Plättchen. NS: nicht signifikant.

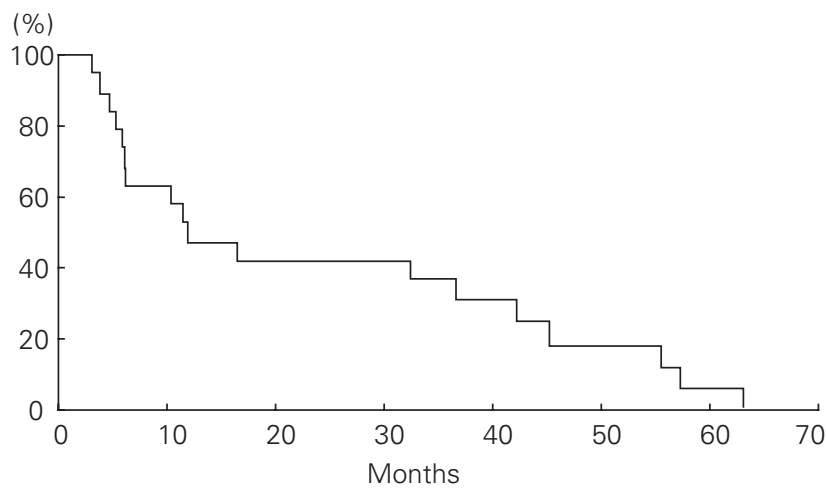

Figure 5. Progression-free survival of 19 hepatocellular carcinoma patients with severe cirrhosis treated with proton beams.

Abbildung 5. Progressionsfreies Überleben der 19 Patienten mit Leberzellkarzinom und schwerer Zirrhose, die eine Protonentherapie erhielten.

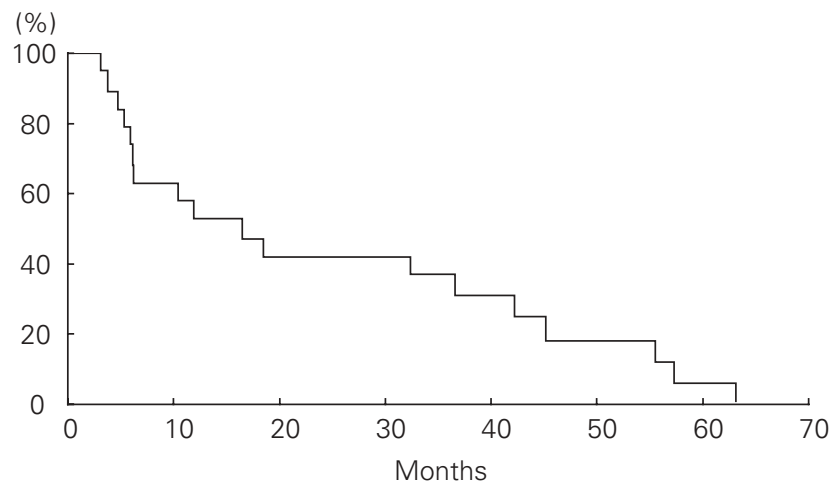

Figure 6. Overall survival of 19 hepatocellular carcinoma patients with severe cirrhosis treated with proton beams.

Abbildung 6. Gesamtüberleben der 19 Patienten mit Leberzellkarzinom und schwerer Zirrhose, die eine Protonentherapie erhielten. 
Table 5. Results of Kaplan-Meier estimate and univariate analysis of prognostic factors for survival. AFP: $\alpha$-fetoprotein.

Tabelle 5. Ergebnisse der Kaplan-Meier-Schätzung und univariaten Analyse der für das Überleben prognostischen Fatoren. AFP: $\alpha$-fetoprotein.

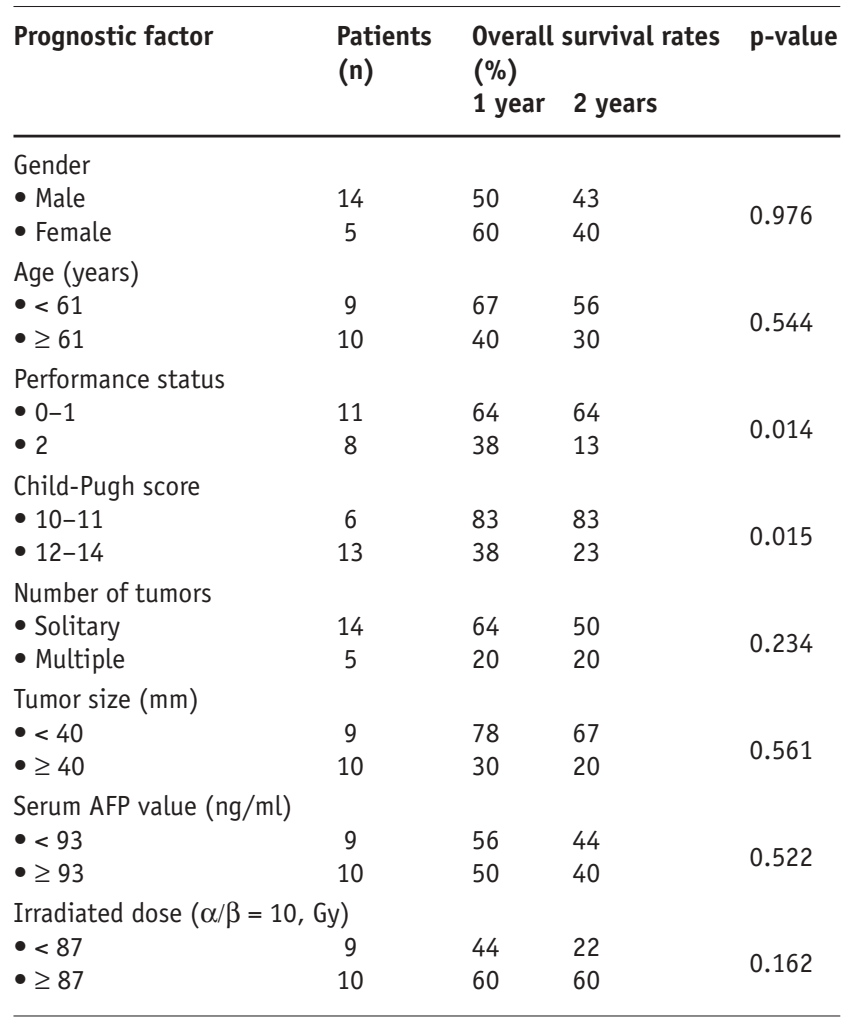

severe cirrhosis [29]. To our knowledge, there was no detailed report on radiation therapy for HCC patients with severe cirrhosis.

In the current study, proton beam therapy appeared to have achieved an improvement in survival for some HCC patients with severe cirrhosis due to excellent local control and reduced toxicity. The overall survival rates of $53 \%$ at 1 year and $42 \%$ at 2 years were better than those of natural course $[3,17,18]$. Performance status and Child-Pugh score were significant prognostic factors for survival. In particular, five of six patients with Child-Pugh scores of 10 and 11 survived for $>2$ years after treatment. By contrast, eight of nine patients who died within 1 year after treatment had Child-Pugh scores of $\geq 12$.

All but one patients (95\%) had no growth of the irradiated tumor while the tumor sizes were $\geq 30 \mathrm{~mm}$ in all patients except one and $\geq 50 \mathrm{~mm}$ in six patients. The objective response rate was $90 \%$ in ten patients who survived for $>1$ year after treatment, and $33 \%$ in nine patients who died within 1 year after treatment. Usually, the tumor volume of HCC reduces gradually over several months, or occasionally over several years, on medical imaging after irradiation. All of the irradiated tumors of six $\mathrm{NC}$ patients tended to reduce in the final
Table 6. Therapy-related acute toxicity according to the acute radiation morbidity scoring criteria (RTOG). Gl: gastrointestinal.

Tabelle 6. Therapiebezogene akute Toxizität entsprechend den ,acute radiation morbidity scoring criteria“ (RTOG). GI: gastrointestinal.

\begin{tabular}{|c|c|c|}
\hline Toxicity & $\begin{array}{l}\text { Grade } \\
1\end{array}$ & 2 \\
\hline $\begin{array}{l}\text { Skin } \\
\text { • Erythema }\end{array}$ & 5 & 1 \\
\hline $\begin{array}{l}\text { Upper GI tract } \\
\text { - Appetite loss }\end{array}$ & 3 & 0 \\
\hline $\begin{array}{l}\text { Lower GI tract including pelvis } \\
\text { - Diarrhea }\end{array}$ & 1 & 0 \\
\hline
\end{tabular}

imaging studies. Since all NC patients died within 1 year after treatment, the intervals between completion of treatment and the last evaluation of treatment efficacy may have been insufficient to achieve an objective response. The dose of $50 \mathrm{~Gy}$ in ten fractions delivered to the one PD patient was the lowest among the present series. This irradiated dose may not have been sufficient for tumor control.

The severe or fatal toxicities which occurred in previous studies with other treatment modalities were not observed at all in this series.

\section{Conclusion}

Proton beam therapy for HCC patients with severe cirrhosis was tolerable. It may improve survival for the patients with relatively good general condition and liver function.

\section{Acknowledgment}

The present study was supported in part by a Grant-in-Aid for Cancer Research (15-9) from the Ministry of Health, Labor, and Welfare of the Japanese Government.

\section{References}

1. Altman DG. Practical statistics for medical research, 2nd edn. London: Chapman \& Hall, 2004.

2. Ando K, Koike S, Kawachi K, et al. Relative biological effectiveness of the therapeutic proton beam at NIRS and Tsukuba University. Nippon Igaku Hoshasen Gakkai Zasshi 1985;45:531-5.

3. Blum HE. Treatment of hepatocellular carcinoma. Best Pract Res Clin Gastroenterol 2005;19:129-45.

4. Chiba T, Tokuuye K, Matsuzaki Y, et al. Proton beam therapy for hepatocellular carcinoma: a retrospective review of 162 patients. Clin Cancer Res 2005;11:3799-805.

5. Cox JD, Stetz J, Pajak TF. Toxicity criteria of the Radiation Therapy Oncology Group (RTOG) and the European Organization for Research and Treatment of Cancer (EORTC). Int J Radiat Oncol Biol Phys 1995;31:1341-6.

6. Di Carlo V, Ferrari G, Castoldi R, et al. Surgical treatment and prognostic variables of hepatocellular carcinoma in 122 cirrhotics. Hepatogastroenterology 1995;42:222-9.

7. Di Stasi M, Buscarini L, Livraghi T, et al. Percutaneous ethanol injection in the treatment of hepatocellular carcinoma. A multicenter survey of evaluation practices and complication rates. Scand J Gastroenterol 1997; 32:1168-73.

8. Ferro D, Saliola M, Quintarelli C, et al. 1-year survey of patients with advanced liver cirrhosis: prognostic value of clinical and laboratory indexes identified by the Cox regression model. Scand J Gastroenterol 1992; 
27:852-6.

9. Franco D, Capussotti L, Smadja C, et al. Resection of hepatocellular carcinoma. Results in 72 European patients with cirrhosis. Gastroenterology 1990;98:733-8.

10. Giorgio A, Tarantino L, Francica G, et al. Percutaneous ethanol injection under sonographic guidance of hepatocellular carcinoma in compensated and decompensated cirrhotic patients. J Ultrasound Med 1992;11:587-95.

11. Hata M, Tokuuye K, Sugahara S, et al. Proton beam therapy for hepatocellular carcinoma with portal vein tumor thrombus. Cancer 2005;104:794-801.

12. Höcht S, Stark R, Seiler F, et al. Proton or stereotactic photon irradiation for posterior uveal melanoma? A planning intercomparison. Strahlenther Onkol 2005;181:783-8.

13. Inada $T$, Tsuji $H$, Hayakawa $Y$, et al. Proton irradiation synchronized with respiratory cycle. Nippon Igaku Hoshasen Gakkai Zasshi 1992;52:1161-7.

14. Kaplan EL, Meier P. Nonparametric estimation from incomplete observations. J Am Stat Assoc 1958;53:457-81.

15. Livraghi T, Bolondi L, Lazzaroni S, et al. Percutaneous ethanol injection in the treatment of hepatocellular carcinoma in cirrhosis. A study on 207 patients. Cancer 1992;69:925-9.

16. Llovet JM. Updated treatment approach to hepatocellular carcinoma. J Gastroenterol 2005;40:225-35.

17. Llovet JM, Bustamante J, Castells A, et al. Natural history of untreated nonsurgical hepatocellular carcinoma: rationale for the design and evaluation of therapeutic trials. Hepatology 1999;29:62-7.

18. Markovič S, Gadžijev E, Štabuc B, et al. Treatment options in Western hepatocellular carcinoma: a prospective study of 224 patients. J Hepatol 1998; 29:650-9.

19. Matsuzaki Y, Osuga T, Saito $Y$, et al. A new, effective, and safe therapeutic option using proton irradiation for hepatocellular carcinoma. Gastroenterology 1994;106:1032-41.

20. Miller $A B$, Hoogstraten $B$, Staquet $M$, et al. Reporting results of cancer treatment. Cancer 1981;47:207-14.

21. Mock U, Bogner J, Georg D, et al. Comparative treatment planning on localized prostate carcinoma. Strahlenther Onkol 2005;181:448-55.

22. Ohara K, Okumura T, Akisada M, et al. Irradiation synchronized with respiration gate. Int J Radiat Oncol Biol Phys 1989;17:853-7.

23. Oken MM, Creech RH, Tormey DC, et al. Toxicity and response criteria of the
Eastern Cooperative Oncology Group. Am J Clin Oncol 1982;5:649-55.

24. Planas R, Ballesté B, Álvarez MA, et al. Natural history of decompensated hepatitis $C$ virus-related cirrhosis. A study of 200 patients. J Hepatol 2004; $40: 823-30$.

25. Pugh RN, Murray-Lyon IM, Dawson JL, et al. Transection of the oesophagus for bleeding oesophageal varices. Br J Surg 1973;60:646-9.

26. Rutz HP, Lomax AJ. Donut-shaped high-dose configuration for proton beam radiation therapy. Strahlenther Onkol 2004;181:49-53.

27. Sobin LH, Wittekind C. TNM classification of malignant tumours, 6 th edn. New York: Wiley-Liss, 2002:81-3.

28. Suit H, Goldberg S, Niemierko A, et al. Proton beams to replace photon beams in radical dose treatments. Acta Oncol 2003;42:800-8.

29. Tateishi R, Shiina S, Teratani T, et al. Percutaneous radiofrequency ablation for hepatocellular carcinoma. An analysis of 1000 cases. Cancer 2005; 103:1201-9.

30. Tokuuye K, Akine $Y$, Kagei K, et al. Proton therapy for head and heck malignancies at Tsukuba. Strahlenther Onkol 2004;180:96-101.

31. Withers HR, Thames HD Jr, Peters LJ. A new isoeffect curve for change in dose per fraction. Radiother Oncol 1983;1:187-91.

\section{Address for Correspondence}

Masaharu Hata, MD

Department of Radiation Oncology

Institute of Clinical Medicine

University of Tsukuba

1-1-1 Tennoudai, Tsukuba

Ibaraki

305-8575 Japan

Phone $(+81 / 29)$ 853-7100, Fax -7102

e-mail:mhata@syd.odn.ne.jp 